\title{
Complex hermeneutic-phenomenological approach as a research orientation
}

\author{
Neiva Cristina da Silva Rego Ravagnoli* \\ Karin Claudia Nin Brauer**
}

\begin{abstract}
The objective of this work is to present the Complex Hermeneutic-Phenomenological Approach as a research orientation based on two doctoral research papers. The justification for the development of this study lies in the opportunity to show how the Complex Hermeneutic-Phenomenological Approach addresses a phenomenon, ensuring no constraints, impositions or frameworks on pre-assumed bases. The Complex Hermeneutic-Phenomenological Approach takes Hermeneutics and Phenomenology as the philosophical orientation of the investigative process, in an inseparable perspective in which, a textualization and interpretation are developed in the light of the epistemology of Complexity, in search for understanding phenomena of human experience. We believe that this research can contribute with different educational areas interested on approaches that allow integration, interaction and dialogue between different knowledge as
\end{abstract}

1 Neiva Ravagnoli completed her doctoral degree in Applied Linguistics and Language Studies at Pontifícia Universidade Católica de São Paulo, Brazil (2017) where she also earned her Master degree in the same area (2012). Furthermore she earned a Master degree in International English Language Teaching and Applied Language Studies at London Metropolitan University, UK (2004), a Specialist degree in English Language at Universidade de Franca, Brazil (2000), and a Bachelor degree in Languages at Universidade de Ribeirão Preto, Brazil (1997). Currently, she is engaged in a research at a post doctoral level, focusing on the Complex Hermeneutic-Phenomenological Approach, which is ongoing in a research group certified by Conselho Nacional de Pesquisa (CNPq) and based on the Program of Postgraduate Studies in Applied Linguistics and Language Studies, at Pontifícia Universidade Católica de São Paulo. nravagnoli@gmail.com

2 Karin Claudia Nin Brauer concluded her doctorate in Applied Linguistics and Language Studies at Pontifícia Universidade Católica de São Paulo (PUC-SP), Brazil, in 2015. She has a Master degree in Languages, Reading and Cognition, at Universidade de Santa Cruz do Sul (Unisc), Rio Grande do Sul (RS), Brazil, in 2009. She has an English Language Specialization degree at Universidade Franciscana (Unifra-RS), in 2000 and also a graduation degree in Languages, with qualification in Portuguese and English, at the same university, in 1998. Currently she is a post doctorate student in Applied Linguistics and Language Studies at Pontifícia Universidade Católica de São Paulo (PUC-SP), Brazil and she is a researcher in Grupo de Pesquisa sobre a Abordagem Hermenêutico-Fenomenológica Complexa (GPeAHFC), also at PUC -SP. She works at Instituto Federal de Educação, Ciência e Tecnologia de São Paulo and at Faculdade de Tecnologia - FATEC Taubaté, SP, Brazil. kcnb76@gmail.com 
an opportunity for interlocution, interconnections and possibilities of interdisciplinary works, which can reflect on an a actions for a (re) construction of new vias to/for academic research.

Keywords: Complex Hermeneutic-Phenomenological Approach; Teachers' Technological SelfHetero-Eco Formation; Anomie.

\section{A abordagem hermenêutico-fenomenológica complexa como uma orientação de pesquisa}

Resumo

O objetivo deste trabalho é apresentar a Abordagem Hermenêutico-Fenomenológica Complexa como orientação de pesquisa, a partir de recortes de duas teses de doutoramento. A justificativa para o desenvolvimento deste estudo reside na oportunidade de mostrar como a Abordagem Hermenêutico-Fenomenológica Complexa aborda um fenômeno sem preconcepções, cerceamentos, imposições ou estruturas pré-assumidas. A Abordagem Hermenêutico-Fenomenológica Complexa toma a Hermenêutica e a Fenomenologia como orientações filosóficas do processo de investigação, em uma perspectiva indissociável, em que a textualização e a interpretação são desenvolvidas à luz da Teoria da Complexidade, em busca de compreender fenômenos da experiência humana. As autoras deste artigo acreditam que possa contribuir com diferentes áreas da educação interessadas em abordagens que favorecem a integração, a interação e o diálogo entre diferentes saberes, como uma oportunidade de interlocução, interconexão e possibilidades de trabalhos interdisciplinares, os quais possam refletir em ações para a (re) construção de novas vias de/para pesquisas acadêmicas.

Palavras chave: Abordagem Hermenêutico-Fenomenológica Complexa; Auto-hetero-eco formação tecnológica de professores; Anomia.

\section{El enfoque complejo hermenéutico-fenomenológico Como orientación de investigación}

\section{Resumen}

El objetivo de este trabajo es presentar el Enfoque Hermenéutico-Fenomenológico Complejo como una orientación de investigación basada en dos trabajos de investigación doctoral. La justificación para el desarrollo de este estudio está en la oportunidad de mostrar cómo aborda el Enfoque Hermenéutico-Fenomenológico Complejo un fenómeno, asegurando que no haya restricciones, imposiciones o marcos sobre bases preestablecidas. En el Enfoque Hermenéutico-Fenomenológico Complejo, la Hermenéutica y la Fenomenología se toman como orientación filosófica del proceso investigativo, en una perspectiva indisociable en la cual, la textualización y la interpretación son motrices del proceso investigativo, que se desarrolla a la luz de la epistemología de la Complejidad, en busca comprensión de fenómenos de la complejidad experiencia humana. Creemos que esta investigación puede contribuir con diferentes áreas educativas interesadas en enfoques que permitan la integración, la interacción y el diálogo entre diferentes conocimientos como una oportunidad para interlocución, interconexiones y posibilidades de trabajos interdisciplinarios, que pueden reflejar en una acción para una (re) construcción de nuevas vías para / para investigación académica.

Palabras clave: Enfoque Hermenéutico-Fenomenológico Complejo; Auto-heteroecoformación tecnológica; Anomia. 


\section{Introduction}

The Complex Hermeneutic-Phenomenological Approach (FREIRE, 2016) (henceforth AHFC) seeks to understand the nature of a phenomenon, from the perspective of the one who experiences it. According to Freire (2016) AHFC has its interest in complex phenomenon of human experience, which it seeks to describe and interpret under the bias of Complexity, to understand its complex essence. In this approach, Hermeneutics and Phenomenology constitute the inseparable philosophical orientations in the investigative process (FREIRE, 2012) that interconnect with the theory of Complexity (MORIN, 2000; 2005).

Thus, Phenomenology, which seeks to establish theoretical-methodological principles for describing the subjectivity of human experiences, understood as phenomena (HEIDEGGER, 1988, p. 207) is taken from an inseparable perspective of Hermeneutics, which is the science of interpretation that seeks, with based on written records, to understand the uniqueness of human experiences (DYTHEY, 1994) and under the bias of Complexity that, according to Morin (2000) in search of an epistemological understanding of reality, considers connection, contextualization, globalization of information, knowledge and disregard the certainties and absolute knowledge.

Freire (2012) purposely hyphenated the term hermeneutic-phenomenological to highlight this inseparable character between the description and interpretation of phenomena of human experience, with the intention of approaching its essence, being aware that it would not be possible to know it completely. It is a paradox that shows that the phenomena of human experience are an inexhaustible source of research, interpretation, and reinterpretation.

Complexity deals with recursion, non-linearity, and non-fragmentation of knowledge, focusing on the contradictions and dialogue that may exist between them. It is weaving of heterogeneous constituents, inseparably associated, which establishes the paradox of the unity and the multiplicity. According to Morin (2005) Complexity also includes uncertainties, indetermination and random phenomena and always has connection to chance.

The investigation in the AHFC (FREIRE, 2012) consists of the description of a phenomenon, through the textualization of experiences and identification of themes that constitute it, form its essence and attribute its identity to it. Such approach involves three processes of interpretation, in which the researcher dedicates himself/herself to readings and re-readings that allow the verification of units of meaning that stand out in function of the senses that have and reveal about the phenomenon under study.

The following table shows such process (FREIRE, 2012): 
Routines of organization and interpretation of texts.

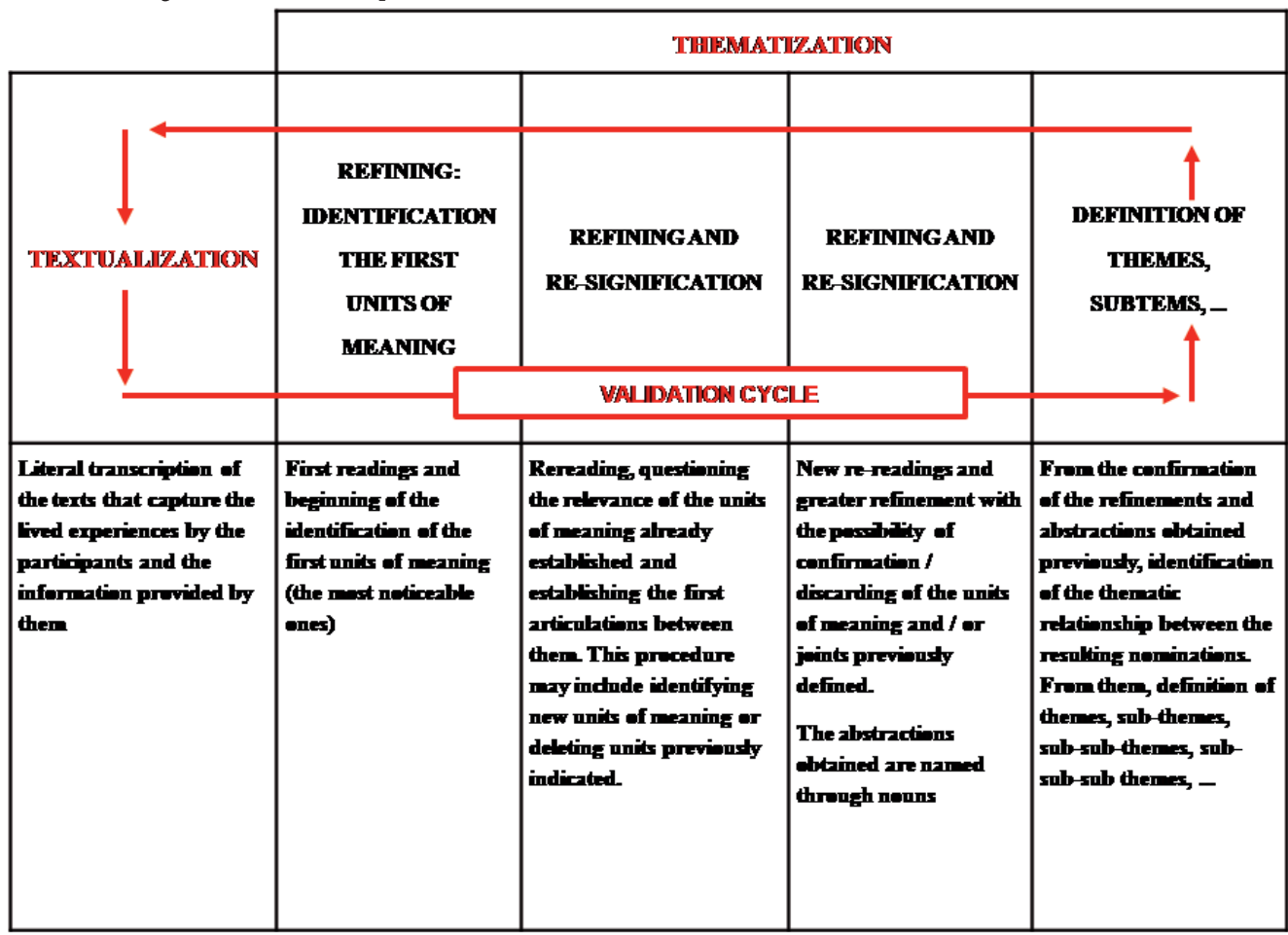

Source: Freire (2007 apud FREIRE, 2010 p .25)

The first process, the textualization, is preceded by the process of data collection, which can be done through interviews, oral or written narratives, viewing sessions, audio or video recordings, hermeneutic conversation, among others. This is the phase through which lived experience is transcribed, which, according to Freire (2012), allows an investigation that not only captures lived experiences but also allows the researcher to take them back many times, favoring reflection and new interpretations.

The second process, the thematization (van MANEN, 1990 apud FREIRE, 2010), is the phase of meaning that stand out in function of the senses that have and reveal about the investigated phenomenon. According to Freire (2012), this process includes a procedure called refinement, which is very important in describing the phenomenon. In this step, a data cross is started: some units of meaning can be maintained, others can be discarded and new units of meaning can be identified.

At this stage, a re-signification of units of meaning may also occur. In this way, the researcher can reassess the units of meaning, reflecting on their relevance to the investigation and confirming or not the first interpretations, being able to reformulate them and rename them, if necessary. According to Freire (2010), these procedures are part of the thematization process and need to be done several times, so that the researcher can get to the hermeneutic-phenomenological themes, which are taken as elements that make up the phenomenon and what is linked to the experience interpreted, characterizing, its essence Freire.

This circular, recursive movement of coming and going, throughout the process of interpretation is what characterizes AHFC. It is an unfinished circularity, in view that reality is not linear and triggers a weave together implied in feedback its constituent elements. 
The retroactivity made during the thematization process, in which the researcher rereads the text to review the relevance of the units of meaning, refine and redefine it establishes the validation cycle, since the objective is to validate the highlighted themes that emerge from the interpretation of the phenomenon.

Freire understands that a noun must express the themes. It is because by naming something, the noun has complete meaning, and so, captures the meaning that re-signifies and refines, outlining the phenomenon completely.

The textualization, thematization and the validation cycle constitute what Freire (2007) calls organization routines, interpretation and validation, distinctive features of AHFC. The objective of this work is to present the AHFC as a research orientation. The justification for the development of this study lies in the opportunity to show how the AHFC addresses a phenomenon, ensuring no constraints, impositions or frameworks on pre-assumed bases.

Therefore, following are two examples taken from doctoral dissertation, with focus on phenomena: design of an English High School teachers' technological self-hetero-eco formation online course under the Complexity bias (BRAUER, 2015) and the manifestation of anomia among teachers of a Continuing Education course for Community School English Teacher (RAVAGNOLI, 2017).

\section{The phenomenon design of an English High School teachers' technological self-hetero-eco formation online course under the Complexity bias}

The present research aimed to describe and to interpret the phenomenon: design of an English High School teachers' technological self-hetero-eco formation online course under the Complexity bias, in order to enable teachers to use technological interfaces and to product online educational materials.

The theoretical framework of this study considering the interpretative issues of its proposal was the epistemology of Complexity (MORIN 2000; 2005), Complex Educational Design (FREIRE, 2013), the production and study of materials and distance learning (VALENTE, 2000, 2007), teacher education (P. FREIRE 2002, 2005) and the technological self-hetero-eco formation process (FREIRE, 2009; FREIRE and LEFFA, 2013).

According to Morin (2005), Complexity understands education as a constant, non-linear, non-reductionist, non-fragmented reconstruction, through a diversity of knowledge that bind and re-connect in different ways. It is relevant to present a theoretical basis that articulates knowledge, since the process of self-hetero-eco formation of teachers constitutes a basic instrument for articulated action in life.

In order to understand the technological self-hetero-eco formation (FREIRE, 2013), it is necessary to mention that Pineau (1988) presents a tripolar theory for the formation of teachers. Freire (2009, p. 18) synthesizes this theory and the author (FREIRE, 2009) further decomposes the terms of this concept, which are presented below:

- self-formation: the action of the self as an individual and social subject; that is, the appropriation by the individual of his own formation, becoming his object; 
- heteroformation: the action of individuals on one another, characterizing the social dimension of formation; that is, the forming;

- eco-formation: the action of the environment on individuals, indicating the environmental and ecological dimension of the training.

It is relevant to mention that in making a deeply study of the tripolar theory of Pineau (1988), Freire (2009, p. 20) points out that:

The perception - one and multiple at the same time - reveals the inherent complexity that characterizes formation and, therefore, the relation between its parts (its poles) and the whole that is not completed, generating a process that is admittedly endless, throughout life and, therefore, in permanent evolution.

Freire (2009, p. 19) elaborates a picture regarding the contrastive view of the ternary conception of the formative processes - self-formation, heteroformation and ecoformation, which is presented below:

Quadro 1 - Contrastive view of the ternary conception of the formative processes

\begin{tabular}{|c|c|c|c|c|}
\hline & \multicolumn{3}{|c|}{ POLES } \\
\hline & & $\begin{array}{l}\text { SELFFORMATION } \\
\text { (personalization) }\end{array}$ & $\begin{array}{c}\text { HETEROFORMATION } \\
\text { (socialization) }\end{array}$ & $\begin{array}{l}\text { ECOFORMATION } \\
\text { (ecologization) }\end{array}$ \\
\hline \multirow{4}{*}{$\begin{array}{l}\frac{n}{2} \\
\frac{0}{0} \\
\frac{n}{2} \\
\frac{5}{0}\end{array}$} & ACTION & $\begin{array}{l}\text { Individual } \\
\text { [action of the individural } \\
\text { upon himself] }\end{array}$ & $\begin{array}{c}\text { Social } \\
\text { [action of individuals on } \\
\text { the others] }\end{array}$ & $\begin{array}{l}\text { Emironmental } \\
\text { fthe reciprocal action of the } \\
\text { emironment on the } \\
\text { individhal] }\end{array}$ \\
\hline & SUBJECT & Individual sulbject & Social subject & Ecological sulbject \\
\hline & $\begin{array}{l}\text { OBJECT OF } \\
\text { FORMATION }\end{array}$ & Subject & The coformation & $\begin{array}{c}\text { The relationship between } \\
\text { the human and the } \\
\text { emironment }\end{array}$ \\
\hline & RELATIONS & $\begin{array}{l}\text { Internak } \\
\text { [primarily] }\end{array}$ & $\begin{array}{l}\text { Extemals } \\
\text { [primarily] }\end{array}$ & $\begin{array}{l}\text { Ecologicals } \\
\text { [primarily] }\end{array}$ \\
\hline
\end{tabular}

Source: Freire and Leffa (2013, p. 70-73)

Freire (2009) opts for the term hyphenated to emphasize the connection and simultaneity of the constituents auto, hetero, and echo that integrate it, releasing the formation of a linear, reductionist, fragmented and simplifying view by highlighting the subjects and their individualities (self), their interrelationships with other (hetero) subjects and their relationships with the environment (echo) in which they form, develop and transform themselves.

The technological self-hetero-eco formation process (FREIRE, 2009; FREIRE; LEFFA, 2013) is understood as a training that is individual, shared and ecological, the self-hetero-eco formation process of teachers demonstrates to be of great relevance in the face of the changes that occur in the present time, such as technological innovation and continuing vocational training. 
According to Freire and Leffa (2013, p. 75), the technological self-hetero-eco formation process is understood as:

Action of the environment - presential and / or digital - on individuals, mediated by singular tools, practices and languages, coupled with a critical-reflexive action of these individuals on the environment, on others and on themselves, appropriating these tools, practices and languages, to use them in a pertinent and adequate way, in the construction / deconstruction / reconstruction of knowledge and its critical insertion in the face and digital worlds, as generative citizens, guardians and interpreters of information that leads to the full formation of self as an individual, social, technological and planetary subject

The technological self-hetero-eco formation process (FREIRE, 2009; FREIRE; LEFFA, 2013) requires the teacher to develop strategies of personal organization and reorganization in which he understands his learning process, deepens knowledge through collaborative interaction. This posture can bring about reflexes in their teaching practice and develop their competence to teach and this may have repercussions in the relationship with their students. In this perspective, complexity serves as the basis for this type of formation, provides for interaction and knowledge construction.

Thus, to develop the design and implementation of the course in this study, as mentioned, Brauer (2015) followed the proposal of Freire (2013), called Complex Educational Design (DEC). The DEC is based on complexity and is concerned with maintaining a dialogue between students' reality and educational actions, as well as addressing the concerns and needs of students, teachers and society.

To achieve these goals, Freire (2013) develops DEC that consists of three stages: preparation, execution and reflection. These stages unfold throughout the course process and occur in an articulated way, interconnected, as can be seen in Figure 2:

According to Freire (2013, p. 181) although DEC understands three stages initially performed in a sequence (that is, when the course is first taught), it is important to remember that the three stages maintain intense, recursive, dialogic connections and holograms that are responsible for the creation of the course as a whole, as well as its subdivisions and its multiple parts. These parts, from the beginning to the end, are naturally oriented by the teacher / designer; however, as soon as interactions begin, command is divided and decisions are made collaboratively with students who are also important parts of the teaching-learning process.

Once the theoretical foundation of this dissertation was presented, the following path is to present the methodology that was used to discuss the phenomenon interpreted. 
Complex Educational Design.

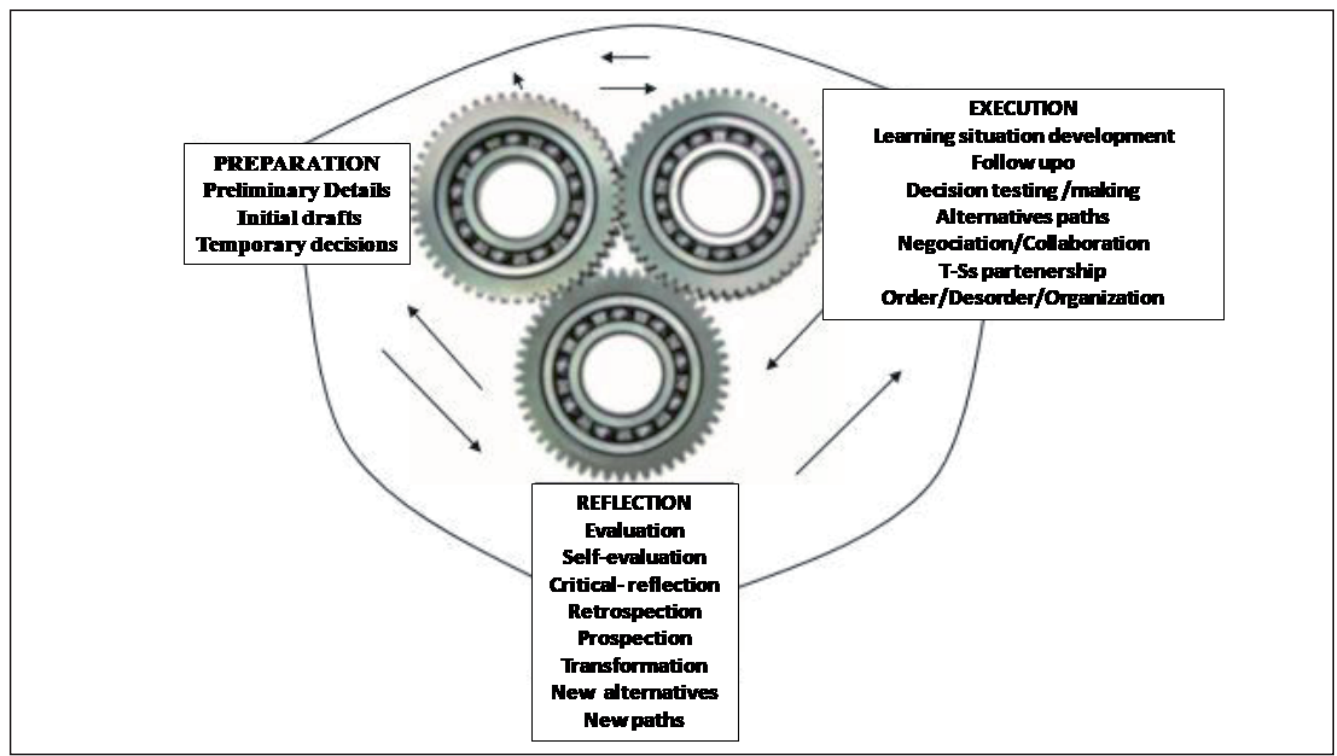

Source: FREIRE (2013, p.181).

The research design of an English High School teachers' technological self-hetero-eco formation online course under the Complexity bias (BRAUER, 2015) was developed through the elaboration of English High School teachers' technological self-hetero-eco formation online course under the Complexity bias and through the reflexive diary of the researcher about the course, to obtain texts that were used for the interpretation of the phenomenon under study which received a hermeneutic- phenomenological treatment, from the perspective of Freire $(2007 ; 2009 ; 2010$, 2012) based on van Manen (1990). The research had English High School teachers of public institutions of São Paulo city as participants.

The interpretations from the perspective of the designer-researcher and of the participants of the course reveal six themes that comprehend the phenomenon which are mentioned now: interfaces, teaching, learning, construction, interaction and needs. The interpretation of these texts revealed the reflection of the participants upon the design of an English High School teachers' technological self-hetero-eco formation online course under the Complexity approach (BRAUER, 2015), as well as providing the research-teacher with reflective moments on the development of the course and on the complex features required for the teaching-learning process.

The following is an example of how the analysis process is conduct.

\begin{tabular}{|c|c|c|c|c|}
\hline \multirow{2}{*}{ TEXTUALIZATION } & \multicolumn{4}{|c|}{ THEMATIZATION } \\
\hline & UNITS OF MEANING & REFINING & RE-SIGNIFICATION & THEME \\
\hline $\begin{array}{l}\text { We can encourage interaction } \\
\text { encourage interaction betwe- } \\
\text { en students and teachers, all } \\
\text { in the same environment. In } \\
\text { Moodle it is possible to realize } \\
\text { all these possibilities perhaps } \\
\text { it is not the best virtual lear- } \\
\text { ning environment, but I think } \\
\text { that if well structured it can be } \\
\text { an inviting environment. }\end{array}$ & $\begin{array}{l}\text { We can encourage interac- } \\
\text { tion between students and } \\
\text { teachers, all in the same } \\
\text { environment. In Moodle it } \\
\text { is possible to realize all the- } \\
\text { se possibilities perhaps it is } \\
\text { not the best virtual learning } \\
\text { environment, but I think } \\
\text { that if well structured it can } \\
\text { be an inviting environment }\end{array}$ & $\begin{array}{l}\text { We can encou- } \\
\text { rage interaction } \\
\text { encourage inte- } \\
\text { raction }\end{array}$ & \begin{tabular}{|l|} 
Interaction \\
\end{tabular} & Interaction \\
\hline
\end{tabular}

SOURCE: Brauer (2015). 
In order to describe and interpret the phenomenon design of an English High School teachers' technological self-hetero-eco formation online course under the Complexity bias, the routines of organization and interpretation proposed by Freire (2007) were followed. Once the experiences were textualized, that is, that the textual record of the occurrence of the phenomenon was made through the annotations of the reflexive diary of the researcher and of the records in the course English High School teachers' technological self-hetero-eco formation online course under the Complexity bias, the texts were read and the excerpts that gave identity and structure to the phenomenon in question were selected. After the selection of these, the themed process was started, according to the routines of organization and interpretation proposed by Freire (2007), beginning the verification of the first units of meaning that were followed by refinements and resignifications.

During the stages, the researcher turned to the texts, both the notes of the reflexive diary and the records made in the course of technological training, with the aim of validating the cycle, enabling and developing the interpretation and a greater understanding of the phenomenon and its essence. In this way, it was possible to identify the themes: interfaces, teaching, learning, construction, interaction, needs and subthemes: time, practice and difficulties that structured the phenomenon in focus and gave it identity, its essence.

It is relevant to observe that the complex characteristics appeared between the themes and the subthemes that constitute the phenomenon design of an English High School teachers' technological self-hetero-eco formation online course under the Complexity bias as the interweaving of these, since all, themes, are linked and one interdepends on the other to happen. For example, the theme of teaching is directly linked to collaborative learning and this will only be developed if there is a collaborative construction of knowledge. This type of construction takes place through interaction; for these themes to occur it is necessary to have the time to enable the activities to interconnect and dialogue, that is, to present complex characteristics.

The complexity is necessary to enable a recursive movement with retroaction and deconstruction and reconstruction of the weeks and it becomes possible in open courses, and according to the Complex Educational Design (FREIRE, 2013) that is concerned with having a construction, attending the needs of the students. The practical theme only emerged because there was interaction of all the others.

All themes and subthemes are woven into a large set as if they were a constantly moving network, making new connections or even reconnecting, constantly interacting, retroacting and dialoguing, realizing that at the same time, they are part and all following the principles of Complexity (MORIN, 2005).

\section{The anomie phenomenon among teachers of a Continuing Education course for Community Schools English teachers}

This research, conducted in the field of Applied Linguistics, aimed to describe and interpret the anomie phenomenon that may emerge from the experiences of teacher-students in a training course, to understand the effects and implications of this phe- 
nomenon in such context. The course is part of a continuing education program for English teachers from community schools.

Anomie is a contingency that particularizes the ways of becoming individuals, in the face of crisis situations motivated by the non-conformity between individual goals and the means available to achieve those goals. Anomia can be defined as indifference, apathy, conformity, resignation or states of nonconformity that are expressed in the form of opposition, revelation, desire for change or social activism.

In the context of a continuing training course, if the program proposals are not clear or are not clearly understood by the teacher-students entering the program, there may be a discrepancy between their goals - such as the completion of the course and the reasons associated with it - and the means available to achieve these goals - course structure, class size, duration, objectives and principles. Under this circumstance, individuals are moved to respond to the situation by expressing states that may lead them to desistance, or by not actually taking advantage of the program, or by taking decisions that are supposed to lead them to better align with the proposals of course.

It is a response to the perceived crisis. According to Morin and Viveret, a crisis (2013, p.10) causes an internal process of disorganization that increases uncertainties, contributes to questions and can stimulate the search for new solutions. In this sense, crises give rise to responsive movements to itself. It is these movements, which is called anomie (RAVAGNOLI, 2017).

This view of anomie expands my understanding of this phenomenon, proposed in Ravagnoli (2012) as a re-reading of the studies of Durkheim (1897/2000) and Merton (1964). In Ravagnoli (2012) anomie is understood as responses that emerge from the confluence between the representations and the identity of the individuals in the face of circumstances of non-conformity between their objectives and the means available to reach those objectives. This article expounds my understanding of anomie, considering this phenomenon in relation to the notion previously proposed in Ravagnoli (2012): an individual response, in which, however, it is not limited only to the manifestations that emerge according to the way in which individuals position and perceive themselves in the world, but it is associated, to the notion of intertwining relations between individuals.

This was shown by the research to which this article refers: the phenomenon anomie emerges from the individual crisis experienced by teacher-students as well from the crises of the other systems in which they are situated, characterizing a moment of truth of the interrelationship between these systems, which oscillate between order and disorder. The emergence of anomia is a revealing element of the crisis in the course and its effects.

The interpretation was based on textualized narratives of 32 teachers-students who report their experiences at the beginning of the course and at the end, according to their criteria of relevance and worldview through narrative interviews (SCHÜTZA, 1983)

Given that anomie is an individual response to the perceived crisis, the thematization process revealed that the participating teachers, when perceiving a dissonance between their expectations regarding the course and the purposes of the same, respond to this situation through three themes: proposal, rupture and re-signification. The first theme - proposal - expresses that teachers, dissatisfied with various aspects of the course, propose a motion, an agreement so that the relation between academy and school 
can be strengthened. The second theme - rupture - reveals that some teachers, enrolled in the course only to obtain a diploma, do not get involved or do not deepen their activities and give up the course. The third theme - re-signification - reveals that teachers enroll in the course, ignoring or disregarding its proposals, but when participating in the context, re-signify their view of teaching and learning.

The interpretation process showed that the themes - proposal, rupture and resignification - emerge from an ecology in which several simultaneously and continuously interwoven movements interrelate with the teacher and the course as well with the teacher and the other contexts in which they participate.

Thus, the themes that characterize anomie reveal the complexity of the course system. In the light of Complexity (Morin, 2015), the course is a unitary and multiple systems. It is unitary (a graduate course, the whole) formed by multiple parts (teachers-students, teacher-trainers and others involved), which is constituted by the interrelationships that develop between them. Thus, it is greater than the sum of the parts because they have properties that no part possessed since they emerge from the interrelationships between individuals. And it is smaller than the parts because it may have characteristics that are inhibited by the organization of the set.

It is the possibility of focusing each part with its specificities, while at the same time relating them to each other in the composition of the whole and in the understanding of the phenomenon investigated is the characteristic that gives particular importance to research oriented by the AHFC.

Based on a metaphor of Morin (2015), it is possible to affirm that, just as in the living organism, the malfunction of a certain organ seeks adaptations that often compromise other organs or assign them new functions or the fragmentation of this equilibrium or order (the dissonance between the objectives of the course and the teacher-students), provokes movements that seek cohesion or new order (MORIN, 2015).

The following is an example of how the analysis process is conduct.

\begin{tabular}{|c|c|c|c|c|}
\hline \multirow[b]{2}{*}{ TEXTUALIZATION } & \multicolumn{4}{|c|}{ THEMATIZATION } \\
\hline & UNITS OF MEANING & REFINING & RE-SIGNIFICATION & $\begin{array}{l}\text { RE-SIGNIFICA- } \\
\text { TION THEME }\end{array}$ \\
\hline $\begin{array}{l}\text { I quickly realized that } \\
\text { the course wouldn't be } \\
\text { easy. [...] Then I started } \\
\text { to feel that I could not } \\
\text { be here because of a cer- } \\
\text { tificate only. [...] } \\
\text { I felt that I should get } \\
\text { myself involved in the } \\
\text { academic subjects. [...] } \\
\text { Later I felt myself em- } \\
\text { barrassed because of my } \\
\text { poor English. [...] } \\
\text { I tried following my col- } \\
\text { leagues, reading more, } \\
\text { studying more, but I } \\
\text { didn't succeed. [...]. So } \\
\text { I thought about drop- } \\
\text { ping out. }\end{array}$ & $\begin{array}{l}\text { The course wouldn't be } \\
\text { easy. } \\
\text { The purpose of the course } \\
\text { is not a certificate only. } \\
\text { I felt myself embarrassed } \\
\text { because of my poor En- } \\
\text { glish } \\
\text { The course presupposes } \\
\text { engagement from the } \\
\text { students } \\
\text { No progress despite hard } \\
\text { working } \\
\text { Dropping out }\end{array}$ & $\begin{array}{l}\text { Difficulty } \\
\text { No commitment } \\
\text { Feeling of shame } \\
\text { Unsuccessful }\end{array}$ & Dropping out & Rupture \\
\hline
\end{tabular}

SOURCE: Ravagnoli (2017). 
The thematization process shows that from the textualization, the units of meaning emerge as an expression of the teacher's difficulties. When refined, these units give a broader sense to such difficulties (no commitment, feeling of shame, unsuccessful, dropping out).

After refinement, the interpretation goes through a re-signification, and the researcher understands that all meanings alluding to difficulties can be expressed by the word dropping out.

Thus, to assign a noun that is intransitively able to identify the nature of the anomie and give it identity, the researcher attributes the noun rupture.

\section{Conclusion}

This project was conceived to show the feasibility of using the Complex Hermeneutic-Phenomenological Approach based on Freire (2016), by presenting the assumptions of the AHFC and briefly illustrating, from two doctoral studies, how investigations based on this approach are structured and developed.

The AHFC makes it possible to understand the nature of the phenomena in focus, through description and interpretation and under the assumptions of complexity: namely, non-linearity, presumption of uncertainties, unexpected or new.

However, what is quite clear is that there is no single approach that can be used to all and every phenomenon investigation. In this way, we believe that this research can contribute with different educational areas that seek to know approaches that allow integration, interaction and dialogue between different knowledge and to provide meaningful learning opportunities and reflection.

\section{Bibliografy}

BRAUER, K. C. N. Auto-heteroecoformação tecnológica de professores de inglês do Ensino Médio em ambiente on-line sob o viés da complexidade. Tese de Doutorado. LAEL. PUC/SP, 2015.

DILTHEY, W. The hermeneutics of the human sciences. In: Mueller- Vollmer, K. (Ed.), The hermeneutics reader: texts of the german tradition from the enlightenment to the present. The Continnum Publishing Company, 1994

DURKHEIM, D. É. [1897]. O Suicídio: Estudo de Sociologia. Tradução de Mônica Stahel. São Paulo: Editora Martins Fontes, 2000.

FREIRE, M. M. A abordagem hermenêutico-fenomenológica em linguística aplicada. Seminário de Pesquisa oferecido no Programa de Estudos Pós-Graduados em Linguística Aplicada e Estudos da Linguagem, PUC-SP, 2007

FREIRE, M. M. Formação tecnológica de professores: problematizando, refletindo, buscando... In: U. Soto, M. F. Mayrink, I. V. Gregolin. (Orgs.), Linguagem, educação e virtualidade - experiências e reflexões. Cultura Acadêmica Editora, 2009.

FREIRE, M. M. Abordagem hermenêutico-fenomenológica como orientação de pesquisa. In: M. M. FREIRE (Org). A pesquisa qualitativa sob múltiplos olhares: estabelecendo interlocuções em Linguística Aplicada. Publicação do GPeAHF, Grupo de Pesquisa sobre a Abordagem Hermenêutico-Fenomenológica. São Paulo, SP, 2010., p.19-29. 
FREIRE, M. M. Da aparência à essência: a abordagem hermenêutico-fenomenológica como orientação qualitativa de pesquisa. In: Jucimara Rojas, Lucrécia Streingheta Mello. (Org.). Educação, pesquisa e prática docente em diferentes contextos. $1^{\text {a }}$ ed.Campo Grande : Life Editora. v. 1, 2012, p. 181-199.

FREIRE, M. M. Complex educational design: a course design model based on complexity. Campus-Wide Information Systems, Vol. 30 No. 3, 2013, p. 174-185.

FREIRE, M. M. Coloquiando sobre a Abordagem Hermenêutico-Fenomenológica Complexa. Apresentação feita no Colóquio sobre a Abordagem Hermenêutico-Fenomenológica Complexa. 6 de maio de 2016. PUC-SP.

FREIRE, M. M.; LEFFA, V. J.. A auto-heteroecoformação tecnológica. In: Luiz Paulo da Moita Lopes (Org). Linguística aplicada na modernidade recente: festschrift para Antonieta Celani. $1^{\mathrm{a}}$ ed. São Paulo: Parábola, 2013, p.59-78.

FREIRE, P. Pedagogia da autonomia: saberes necessários à prática educativa. Rio de Janeiro: Paz e Terra, 2002.

FREIRE, P. Pedagogia do oprimido. Rio de Janeiro: Paz e Terra, 2005.

MERTON, R. R. Anomie, anomia, and social interaction: Contexts of deviant behavior. In: Marshall Barron Clinard (Ed), Anomie and deviant behavior, New York: The Free Press, 1964. p. 213-242.

MORIN, E. Introdução ao Pensamento Complexo. Tradução de Eliane Lisboa: Editora Sulina. 2005.

MORIN, E. A cabeça bem-feita: repensar a reforma, reformar o pensamento. Tradução de Eloá Jacobina. Rio de Janeiro: Bertrand Brasil, 2000.

MORIN, E. Entender o mundo que nos espera. In: MORIN, Edgar; VIVERET, Patrick. Como viver em tempo de crise? Tradução de Clovis Marques. Rio de Janeiro: Bertrand Brasi, 2013. p. 7-27.

MORIN, E. Ensinar a viver: manifesto para mudar a educação. Tradução Edgard de Assis Carvalho e Mariza Perassi Bosco. Porto Alegre: Sulina, 2015.

PINEAU, G. A autoformação no decurso da vida: entre hetero e a ecoformação. In: NÓVOA, A.; FINGER, M. (Org.). O método (auto)biográfico e a formação. Lisboa: Ministério da Saúde, p.65-77, 1998.

RAVAGNOLI, N. C. S. R. A manifestação da anomia nas representações de professores e alunos de inglês da escola pública: um estado de exceção de (d)Direito. 2012. 233f. Dissertação (Mestrado) - Pontifícia Universidade Católica de São Paulo, São Paulo, 2012.

RAVAGNOLI, N. C. S. R. A anomia em um curso de formação contínua de professores de inglês da escola pública: um olhar complexo. 2017. 142 f. Tese (Doutorado em Linguística Aplicada e Estudos da Linguagem) - Pontifícia Universidade Católica de São Paulo, São Paulo, 2017.

SCHÜTZE, Fritz. [1983]. Pesquisa Biográfica e entrevista narrativa. Metodologias de pesquisa qualitativa na educação: teoria e prática. Tradução de Denilson Werle; revisão de Wivian Weller.Petrópolis: Vozes. 2010. [Publicado originalmente em: Neue Praxis, 1, 1983, p. 283-293]. 
soxesepo 